\title{
WOJCIECH SADŁOŃ \\ Duszpasterskie rady parafialne w Polsce na podstawie badań empirycznych
}

Parafialne rady duszpasterskie są zjawiskiem stosunkowo nowym, wyrosłym $\mathrm{z}$ ducha eklezjologii posoborowej, $\mathrm{w}$ tym $\mathrm{z}$ idei wspólnotowego charakteru parafii oraz kształtowania tej ostatniej w klimacie współodpowiedzialności także parafian świeckich za realizację misji Kościoła w określonych warunkach miejsca i czasu. Celem rady ma być współpraca świeckich w rozwijaniu aktywności duszpasterskiej w parafii na poziomie instytucjonalnym oraz przekształcanie parafii we wspólnotę ${ }^{1}$. Rady te są czymś innym i nowym w stosunku do tradycyjnych rad parafialnych, działających u nas na podstawie Statutu Rad Parafialnych przyjętego przez Konferencję Episkopatu Polski 7 września 1947 roku, a programowo nastawionych na współpracę z proboszczem przy zawiadywaniu przezeń majątkiem parafii ${ }^{2}$. Zadania rad duszpasterskich, o których Sobór wypowiadał się aż $\mathrm{w}$ trzech dokumentach, miały być inne; w istocie określone nazwą nowego gremium. W warunkach polskich znaczenie mają do dziś „Wytyczne dla Parafialnych Rad Duszpasterskich" przyjęte przez Konferencję Episkopatu Polski 18 listopada 1975 roku $^{3}$. W tym i w innych dokumentach kościelnych parafialne rady duszpasterskie wzorowane są na diecezjalnych radach duszpasterskich; mają być niejako odwzorowaniem tych ostatnich na szczeblu parafii. Jedne i drugie mają mieć $\mathrm{w}$ istocie charakter doradczy.

Wojciech S A D Ł O N SAC, ks. dr, Instytut Statystyki Kościoła katolickiego, członek Europejskiego Towarzystwa Socjologicznego oraz Europejskiej Sieci Badawczej Filantropii, Warszawa, e-mail: w.sadlon@iskk.pl

${ }^{1}$ Kongregacja ds. Duchowieństwa, Instrukcja »Kapłan Pasterz i Przewodnik Wspólnoty Parafialne«, Watykan 2001 p. 26.

${ }^{2}$ Statut Rad Parafialnych. Wrocław 1947.

${ }^{3}$ Wytyczne w sprawie Parafialnych Rad Duszpasterskich, „Wiadomości Archidiecezjalne Warszawskie". R. 1976 nr 1-2. 
Parafialne rady duszpasterskie doczekały się - także w warunkach polskich pewnych opracowań o teologiczno-pastoralnym ${ }^{4}$ oraz prawno-kanonicznym ${ }^{5}$ charakterze, brak było jednak dotąd szerszych badań empirycznych tego nowego zjawiska. Owszem, pewne przyczynki można było znaleźć w literaturze obcojęzycznej. W jednej z niewielu prac opisujących funkcjonowanie oraz oddziaływanie duszpasterskich rad parafialnych $\mathrm{M}$. Cieslak opisuje rolę rady parafialnej poprzez kategorię zaangażowania oraz responsywności ${ }^{6}$. Także u nas przyglądano się radom przez pryzmat postulatu podmiotowości laikatu i jego doświadczenia współodpowiedzialności ${ }^{7}$.

Tymczasem dobrze się stało, że dzięki inicjatywie Komisji Duszpasterstwa Konferencji Episkopatu Polski, we współpracy z Fundacją Renovabis, Instytut Statystyki Kościoła Katolickiego przeprowadził w ostatnich latach pierwsze ogólnopolskie badania parafialnych rad duszpasterskich. Wstępna edycja badania odbyła się w 2007 r., kolejna w 2012 r. i obejmowała wszystkie parafie w Polsce. W toku badań udało się uzyskać dane z 9.213 parafii, co oznacza, że braki danych stanowią 12,7\%. Dodatkowo w 2013 roku przeprowadzono tak zwane jakościowe badanie proboszczów oraz członków rad parafialnych w najbardziej aktywnych parafiach w Polsce. Zrealizowano cztery zogniskowane wywiady (fokusy) z 41 przedstawicielami wspólnot $\mathrm{z}$ trzech regionów duszpasterskich w Polsce (południowy-wschód, północny-zachód i rejon centralny). Pytania dotyczyły norm funkcjonowania rady, komunikacji w radzie, poczucia bycia potrzebnym w radzie, więzi pomiędzy członkami, motywacji uczestnictwa w radzie, uczuć związanych $z$ byciem $w$ radzie, postrzegania rady przez parafian i członków rady, skuteczności rady, przełożenia działalności rady na poziom wiary, poczucia odpowiedzialności za parafię oraz miejsca świeckich w parafii. Natomiast wywiady indywidualne przeprowadzone z 27 proboszczami parafii, w których funkcjonują duszpasterskie rady parafialne, pozwoliły spojrzeć na działanie rady od strony

4 Zob. np. M. B ronikowski: Parafialna rada duszpasterska. Wizja teologicznopastoralna. „Warszawskie Studia Pastoralne”. R. 2007 nr 6; R. K a m i ń s k i: Powołanie i funkcjonalność Parafialnej Rady Duszpasterskiej. „Ateneum Kapłańskie”. R. 1977 z. 412; T e n ż e: Rola Parafialnych Rad Duszpasterskich $w$ życiu wspólnot parafialnych i diecezji. „Roczniki Teologiczne". T. 40: 1993 z. 6; S. W ó j t o w i c z: Posoborowa koncepcja Rady Duszpasterskiej w parafii, „Homo Dei”. R. 1980 nr 3.

${ }^{5}$ Zob. np. J. Gręźli k o w sk i: Rady parafialne $w$ prawie kanonicznym $i$ w życiu parafialnym. „Homo Dei”. R. 1992 nr 2-3; R. S o b a ń s k i: Uwagi o strukturze Parafialnej Rady Duszpasterskiej. „Ateneum Kapłańskie”. R. 1973 z. 387.

${ }^{6}$ M. J. C i e s l a k: Parish Responsiveness and Parishioner Commitment. "Review of Religious Research". R. 1984 nr 2 s. 132-147.

${ }^{7}$ A. P o t o c k i: Parafialne rady duszpasterskie - pomyst na podmiotowość laikatu i demokratyzacje struktur w Kościele katolickim? W: Wybrane problemy demokracji i podmiotowości. Wprowadzenie. Red. K. W i e 1 e c k i. Warszawa 2010 s. 151-170; K. P ó 1 t o r a k: Współodpowiedzialność $i$ uczestnictwo $w$ życiu Kościoła. Rady diecezjalne i parafialne 40 lat po Soborze Watykańskim II. W: Recepcja wskazań Soboru w życiu i działalności Kościoła w Polsce. Red. K. P ół t o r a k. Szczecin 2006 s. 119-144. 
proboszcza. Zostali oni wybrani w sposób celowy w 10 różnych diecezjach w kraju. W badaniu wykorzystano sieć ankieterską ISKK. Badania jakościowe obejmowały tak zwane dobre praktyki, czyli te parafie, gdzie w skali kraju duszpasterskie rady parafialne funkcjonują najprężniej.

\section{Liczebność parafialnych rad duszpasterskich w Polsce}

Przy uwzględnieniu braku danych, w 2012 roku parafialne rady duszpasterskie istniały $\mathrm{w} 70 \%$ parafii $\mathrm{w}$ Polsce. Zakładając natomiast, że braki danych są losowe, wolno oszacować, iż 80\% parafii w Polsce dysponuje radami duszpasterskimi.

Tab. 1. Obecność rady duszpasterskiej a typ parafii

\begin{tabular}{|c|c|c|c|c|}
\hline \multirow[b]{2}{*}{ Typ parafii } & \multirow[b]{2}{*}{ Ogółem } & \multicolumn{3}{|c|}{ W parafii istnieje rada duszpasterska } \\
\hline & & tak & nie & brak danych \\
\hline $\mathrm{N}$ & 10.150 & 7.117 & 1.742 & 1.291 \\
\hline & \multicolumn{4}{|c|}{$\mathrm{W}$ procentach } \\
\hline Ogółem & 100 & 70,1 & 17,2 & 12,7 \\
\hline Miejska & 100 & 77,7 & 22,3 & - \\
\hline Miejsko-wiejska & 100 & 80,1 & 19,9 & - \\
\hline Wiejska & 100 & 81,2 & 18,8 & - \\
\hline Diecezjalna & 100 & 80,4 & 19,6 & - \\
\hline Zakonna & 100 & 79,3 & 20,7 & - \\
\hline
\end{tabular}

Źródło: ISKK

Istnienie w parafii rady duszpasterskiej nie jest zasadniczo związane $\mathrm{z}$ charakterem parafii. Środowisko lokalne nie ma tu wielkiego znaczenia. Nieznacznie rzadziej parafialne rady duszpasterskie funkcjonują w miastach, co zapewne wynika $\mathrm{z}$ trudniejszego tutaj kontaktu proboszcza $\mathrm{z}$ wiernymi. Dla obecności rad duszpasterskich nie ma też znaczenia, czy parafia prowadzona jest przez księży diecezjalnych czy zakonnych. Wśród parafii zakonnych jest niemal taki sam odsetek parafii gdzie nie istnieje rada, jak wśród parafii diecezjalnych. Natomiast wyraźne różnice $\mathrm{w}$ częstotliwości istnienia rad występują między diecezjami. W takich diecezjach jak tarnowska i opolska czy archidiecezja lubelska odsetek parafii z duszpasterskimi radami parafialnymi przewyższa 97\%. Na drugim biegunie skali znajdujemy diecezje, w których odsetek parafii z radami jest kilkakrotnie niższy. Są to diecezje radomska (29\%) i kielecka (37\%) oraz archidiecezja łódzka (41\%). 
Tab. 2. Parafie z parafialnymi radami duszpasterskimi według diecezji (w \%)

\begin{tabular}{|c|c|c|}
\hline & Rada istnieje & Rada nie istnieje \\
\hline Diecezja (archidiecezja) & 80,3 & 19,7 \\
\hline białostocka & 69,1 & 30,9 \\
\hline bielsko-żywiecka & 77,2 & 22,8 \\
\hline bydgoska & 89,9 & 10,1 \\
\hline częstochowska & 67,3 & 32,7 \\
\hline drohiczyńska & 69,1 & 30,9 \\
\hline elbląska & 56,8 & 43,2 \\
\hline ełcka & 89,9 & 10,1 \\
\hline gdańska & 78,7 & 21,3 \\
\hline gliwicka & 95,3 & 4,7 \\
\hline gnieźnieńska & 96,1 & 3,9 \\
\hline kaliska & 85,1 & 14,9 \\
\hline katowicka & 96,8 & 3,2 \\
\hline kielecka & 37,1 & 62,9 \\
\hline koszalińsko-kołobrzeska & 76,8 & 23,2 \\
\hline krakowska & 84,0 & 16,0 \\
\hline legnicka & 85,8 & 14,2 \\
\hline lubelska & 97,1 & 2,9 \\
\hline łomżyńska & 67,0 & 33,0 \\
\hline łowicka & 75,2 & 24,8 \\
\hline łódzka & 40,5 & 59,5 \\
\hline opolska & 97,3 & 2,7 \\
\hline ordynariat polowy & 56,7 & 43,3 \\
\hline pelplińska & 93,5 & 6,5 \\
\hline płocka & 86,9 & 13,1 \\
\hline poznańska & 92,1 & 7,9 \\
\hline przemyska & 92,6 & 7,4 \\
\hline przemysko-warszawska (gr-kat) & 87,1 & 12,9 \\
\hline radomska & 28,8 & 71,2 \\
\hline rzeszowska & 94,5 & 5,5 \\
\hline sandomierska & 73,1 & 26,9 \\
\hline siedlecka & 94,6 & 5,4 \\
\hline sosnowiecka & 45,0 & 55,0 \\
\hline szczecińsko-kamieńska & 70,2 & 29,8 \\
\hline świdnicka & 76,1 & 23,9 \\
\hline tarnowska & 98,4 & 1,6 \\
\hline toruńska & 93,3 & 6,7 \\
\hline warmińska & 60,5 & 39,5 \\
\hline
\end{tabular}




\begin{tabular}{|l|l|l|}
\hline warszawska & 84,1 & 15,9 \\
\hline warszawsko-praska & 77,8 & 22,2 \\
\hline włocławska & 75,2 & 24,8 \\
\hline wrocławska & 81,6 & 18,4 \\
\hline wrocławsko-gdańska (gr-kat) & 87,0 & 13,0 \\
\hline zamojsko-lubaczowska & 96,0 & 4,0 \\
\hline zielonogórsko-gorzowska & 79,0 & 21,0 \\
\hline
\end{tabular}

Źródło: ISKK

$\mathrm{O}$ intensywnym procesie tworzenia parafialnych rad duszpasterskich w ostatnich latach świadczy stosunkowo krótki czas istnienia rad w poszczególnych diecezjach. Najmłodsze rady parafialne są w diecezji warszawsko-praskiej. Tam przeciętna duszpasterska rada parafialna liczy jedynie dwa lata. Najstarsze duszpasterskie rady są natomiast $\mathrm{w}$ diecezji bielsko-żywieckiej oraz $\mathrm{w}$ archidiecezjach białostockiej i gdańskiej, a zostały założone przed 12 laty.

Tab. 3. Średni czas istnienia parafialnych rad duszpasterskich według diecezji

\begin{tabular}{|l|c|}
\hline \multicolumn{1}{|c|}{ Diecezja (archidiecezja) } & Średni czas (w latach) \\
\hline warszawsko-praska & 1,77 \\
\hline legnicka & 2,36 \\
\hline wrocławsko-gdańska (gr-kat) & 4,09 \\
\hline lubelska & 4,60 \\
\hline zamojsko-lubaczowska & 4,61 \\
\hline siedlecka & 5,50 \\
\hline gnieźnieńska & 5,94 \\
\hline kaliska & 6,49 \\
\hline opolska & 6,77 \\
\hline zielonogórsko-gorzowska & 6,86 \\
\hline ełcka & 6,89 \\
\hline częstochowska & 7,15 \\
\hline warszawska & 7,61 \\
\hline poznańska & 7,69 \\
\hline przemyska & 7,73 \\
\hline przemysko-warszawska (gr-kat) & 7,76 \\
\hline świdnicka & 8,03 \\
\hline łomżyńska & 8,38 \\
\hline tarnowska & 8,85 \\
\hline koszalińsko-kołobrzeska & 9,32 \\
\hline warmińska & 9,53 \\
\hline drohiczyńska & 9,57 \\
\hline & \\
\hline & \\
\hline
\end{tabular}




\begin{tabular}{|l|l|}
\hline włocławska & 9,59 \\
\hline bydgoska & 9,85 \\
\hline katowicka & 9,89 \\
\hline radomska & 9,98 \\
\hline ordynariat polowy & 10,00 \\
\hline płocka & 10,04 \\
\hline wrocławska & 10,09 \\
\hline krakowska & 10,26 \\
\hline sandomierska & 10,40 \\
\hline kielecka & 10,44 \\
\hline sosnowiecka & 10,64 \\
\hline rzeszowska & 10,81 \\
\hline szczecińsko-kamieńska & 10,88 \\
\hline gliwicka & 10,94 \\
\hline łowicka & 11,29 \\
\hline pelplińska & 11,84 \\
\hline elbląska & 12,00 \\
\hline łódzka & 12,14 \\
\hline toruńska & 12,29 \\
\hline gdańska & 13,94 \\
\hline białostocka & 14,23 \\
\hline bielsko-żywiecka & 17,00 \\
\hline Źrdo: ISKK & \\
\hline
\end{tabular}

Źródło: ISKK

\section{Dwa modele rad}

Krótki czas istnienia rad duszpasterskich wskazuje, że w Polsce mamy do czynienia $\mathrm{z}$ procesem krystalizowania się struktur wewnątrz-parafialnych. Niejednokrotnie nie istnieje wyraźny rozdział pomiędzy duszpasterską radą parafialną a tradycyjną radą parafialną, tą o $\mathrm{w}$ istocie gospodarczym charakterze. Co więcej, badania wskazują, że rady duszpasterskie bardzo często zajmują się sprawami ekonomicznymi parafii. Jednocześnie obserwuje się zjawisko przekształcania rad ekonomicznych (lub rady budowy kościoła) $\mathrm{w}$ rady duszpasterskie.

W Polsce dominuje tak zwany ekspercki model duszpasterskiej rady parafialnej. Taka rada składa się $\mathrm{z}$ osób, których uczestnictwo w radzie wynika z pełnionego zawodu, bądź roli społecznej. Ten model rady trafnie obrazują następujące wypowiedzi zebrane w badaniach: Proboszcz nie tak, żeby co powie to jest świętość, ale wystuchuje nas, wstuchuje się w to co mówimy jako fachowców, 
bo jesteśmy inżynierami, budowlańcami, i tutaj jesteśmy takim ciałem doradczym, a spraw religijnych to nie dyskutujemy, bo proboszcz mówi, że tak robimy $i$ tak jest... bo tak powinno być (K-23:10) ${ }^{8}$. Do rady wybierane są osoby, które swoimi kompetencjami potrafią doradzić głównie w gospodarczych sprawach, o czym świadczą wypowiedzi: To nie jest tak, że ksiadz proboszcz musi sam zabiegać o wszystko. Ty pracujesz tu, ty załatwiasz to, ty tamto (Sz-26:45). Gdy bezpośrednio coś potrzeba, to wtedy proboszcz się zwraca do elektryka, czy kogoś innego, dziedzinami (...) raczej [proboszcz kontaktuje się] indywidualnie, gdy trzeba żeby ktoś załatwit kopare czy tam coś i dana osoba wie, gdzie się udać i jak to załatwić (Sz-24:20). Zdarza się, że do rady wybierane są osoby, które pełnią już w społeczności lokalnej funkcje społeczne, na przykład sołtysi. Ekspercki model rady duszpasterskiej ma często wychylenie zadaniowe. Taka rada służy realizacji konkretnych inicjatyw w parafii i jest zwoływana zależnie od podejmowanych prac: Spotkań takich to tak nie ma, po prostu, jest jak coś trzeba, czy biskup jest, czy jest jakaś uroczystość, właczamy się i każdy stuży swoja pomoca (W:04:12:21). Wyraźnie posiada ona charakter działaniowy, a nawet ściśle ekonomiczny, a nie doradczy i duszpasterski.

$\mathrm{Z}$ drugiej jednak strony taki model rady jest bardzo pomocny proboszczowi. Członkowie z tak ukształtowanej rady duszpasterskiej stają się jakby „gwardią” proboszcza: witają biskupa gdy przyjeżdża do parafii, organizują procesje, troszczą się o inwestycje oraz budynek świątyni. Ten rys rady parafialnej dobrze oddają następujące wypowiedzi: Wykorzystanie rady, żeby coś zrobić [np.] ottarze przewieźć jest na porządku dziennym (...) wszystkie doraźne sprawy opieraja się przede wszystkim na radnych (...) bo pomimo, że jest dużo ludzi w parafii, zawsze jest problem, żeby ktoś coś zrobit (W-02:37:02). Pan ma dużo sprzętu, trzeba odśnieżyć przy kościótku, jedzie, jest na telefon (...) w naszej radzie dobrze nam się pracuje (Sz-58:13).

Drugim modelem rady, jaki obserwuje się w Polsce, to reprezentacyjna rada duszpasterska. Opiera się ona przede wszystkim na istniejących w parafii wspólnotach, organizacjach, stowarzyszeniach, ruchach. Do rady duszpasterskiej wchodzą najczęściej niejako z urzędu przedstawiciele poszczególnych wspólnot: na przykład Żywego Różańca, Domowego Kościoła czy Odnowy w Duchu Świętym. W taki sposób wypowiadają się o modelu reprezentacyjnym rad ich członkowie: W radzie sa wszystkie grupy parafialne (W2:01:42:50); rada parafialna to byt taki matecznik dla grup parafialnych (...) wszyscy organizatorzy życia parafialnego spotykali się na spotkaniach rady parafialnej (W2:01:48:11), czy wreszcie wcześniej rada nie istniała, ale istniaty wspólnoty (W-03:57:20). Taki model rady dominuje w miastach. Drugorzędną rolę odgrywają tu kompetencje zawodowe po-

\footnotetext{
${ }^{8}$ Wypowiedzi z grup fokusowych oznaczone zostały za pomocą pierwszych liter nazw miast, w których się odbywały (K - Kraków, Sz - Szczecin, W - Warszawa). Cyfry oznaczają natomiast moment (czas) pojawiania się wypowiedzi w zapisach wywiadów.
} 
szczególnych radnych. Natomiast tak ukształtowane rady parafialne częściej niż eksperckie spełniają funkcję doradczą w parafii.

Funkcjonowanie parafialnych rad duszpasterskich w Polsce można więc przedstawić w dwóch wymiarach. Pierwszy z nich dotyczy kompetencji indywidualnych członków rady i przebiega od funkcji czysto eksperckich, gdzie liczą się pojedyncze i indywidualne umiejętności radnego, po funkcję reprezentacyjną, która wynika z zaangażowania w określonej wspólnocie (organizacji) parafialnej. Drugi wymiar dotyczy roli, jaki pełni rada (jako całość) w stosunku do proboszcza i parafii oraz przebiega od czysto zadaniowej roli, gdy rada sama podejmuje konkretną pracę $\mathrm{w}$ parafii, aż po rolę doradczą, gdy rada nie wykonuje wymiernych prac dla parafii, ale służy jako organ doradczy i wspierający proboszcza. Graficznie przedstawia to poniższa rycina.

Rys. 1. Wymiary funkcjonowania parafialnych rad duszpasterskich w Polsce

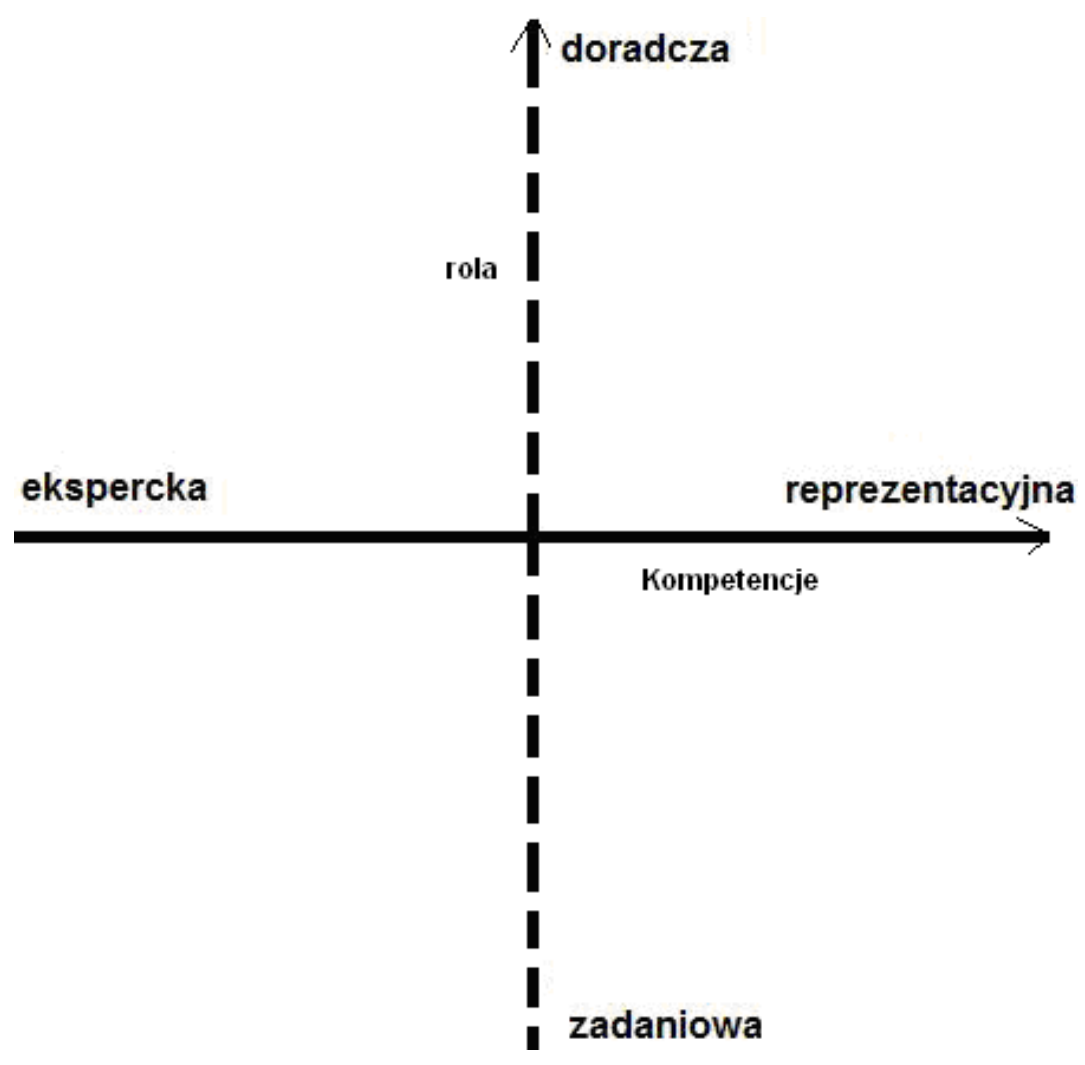


Każdą z funkcjonujących w Polsce parafialnych rad duszpasterskich można umiejscowić w powyższym dwuwymiarowym układzie. Każda rada ma swoje miejsce, ponieważ każda z sobie właściwym natężeniem jest radą ekspercką albo reprezentacyjną oraz jednocześnie doradczą albo zadaniową.

\section{Postrzeganie rady przez jej czlonków}

Radni w polskich parafialnych radach duszpasterskich potrafią krytycznie spojrzeć na funkcjonowanie własnej rady. Znają metody doboru jej członków, dostrzegają mechanizmy funkcjonowania zespołu. Jednocześnie niemal powszechnie są świadomi, że rada jest tylko ciałem doradczym. Widzą też niebezpieczeństwo przerodzenia się rady wyłącznie w klub dyskusyjny. Nie obserwuje się dążeń do dominacji rady duszpasterskiej nad proboszczem. Z wypowiedzi członków przebija głębokie zatroskanie o własną parafię, a jednocześnie przekonanie o istotnej roli własnej rady. Ponadto $\mathrm{w}$ badanych radach duszpasterskich, które - przypomnijmy - stanowią przykłady „dobrych praktyk” - zaobserwowano bardzo pozytywne nastawienie członków. Przykładowo w taki sposób oceniano ich funkcjonowanie: To się odbywa $w$ atmosferze przyjaznej (...) wszystko jest jasne, czytelne i skuteczne (Sz-28:30). Nie ma zgrzytów i konfliktów (W-04:04:18).

Radni również z dużym zaangażowaniem wyrażali się na temat skuteczności funkcjonowania swojej rady duszpasterskiej, przedstawiając konkretne rezultaty pracy. Uważają, że działająca rada jest zabezpieczeniem interesów parafii, co wyrażają w ten sposób: pewne rzeczy kadrowe, gdzie proboszcz potrzebowat podparcia decyzja rady, to sa delikatne sprawy, które zrobity ferment w catej parafii (K-39:36). Ponadto rada potrafi ugruntować decyzje proboszcza, o czym świadczy wypowiedź: Proboszcz [w decyzjach] podpiera się tym, że rada parafialna wspólnie podjęła $z$ nim decyzje $i w$ zwiazku z tym niejako przerzuca odpowiedzialność $n a$ [członków rady] (W-02:28:33). Ponadto sprawna rada stanowi niejako gwarancję ciągłości w funkcjonowaniu parafii, na co wskazują poniższe wypowiedzi: Jestem powolany $w$ radzie przez bytego proboszcza, proboszcz nam się zmienit w ubieglym roku (..) a rada się ni e zmienita, tylko jeden człowiek doszedt (W-04:22:55) lub W zasadzie jest to stała grupa [rada] która jest pomocna wszystkim proboszczom tej parafii, obecnie jest trzeci proboszcz (W-04:25:50).

Radni często znają historię własnej parafii i wyrażają się z troską o swoich duszpasterzach. Nierzadko są dumni z bycia członkiem rady oraz świadomi odpowiedzialności z tym związanej. Wyrażają się w ten sposób: W naszej parafii dużo się dzieje, jesteśmy dumni, ̇̇e możemy w takiej radzie działać (W-04:07:50). Przekonani są jednak również o tym, że Człowiek jest czasem krytykowany przez parafian, coście tam uchwalili, coście tam podjęli jakaśs decyzje (K-36:03). Uczestnictwo w radzie duszpasterskiej wpływa na poczucie przynależności do 
parafii do tego stopnia, że członkowie rad duszpasterskich nazywają mieszkańców parafii „swoimi parafianami”. Oto przykłady takich wypowiedzi: Jak rozmawiam ze swoimi parafianami (W-03:11:02) lub Myślę, że nasi parafialnie to nie sq ludzie zamożni (W2-01:38:45).

Rada według opinii jej członków stanowi ogniwo pośrednie pomiędzy proboszczem i wiernymi. Świeccy tworzący duszpasterskie rady parafialne niejednokrotnie wprost mówią o sobie: Jestem taki tacznik proboszcz-parafia (W-03:13:35). Dlatego mieszkańcy parafii często zwracają się do członków rady w sprawach dotyczących parafii.

Jednocześnie wyniki badań wskazują na odmienność funkcjonowania rady duszpasterskiej w małych parafiach wiejskich oraz w dużych miastach. Na wsi taka rada stanowi swoisty lokalny parlament, bo wszyscy $w$ parafii wiedza, kto jest $w$ radzie (K-28:44). W dużych miastach natomiast członkowie rady są często anonimowi nie tylko dla mieszkańców parafii, ale również dla wiernych.

Niejednokrotnie członkowie rad skarżą się na stosunkowo małe zainteresowanie sprawami duszpasterskimi parafii. Jeden z członków rady na południu Polski w ten sposób wyraża się na ten temat: ludzi interesuje parafia $w$ minimalnym stopniu. Ich interesuje tzw. przejrzystość, to żeby im ksiadz proboszcz powiedziat kawa na tawe (K-01:10:47).

\section{Sposób powoływania rady i jej skład}

Członkowie parafialnych rad duszpasterskich trafiają do nich przede wszystkim z nominacji proboszcza i z wyboru parafian. Tak dzieje się w $70,9 \% \mathrm{rad}$. Natomiast tylko z nominacji proboszcza pochodzi skład 27,7\% rad. Często proboszcz ma wpływ na skład rady nie tylko przez mianowanie bezpośrednie, ale również prosząc konkretne osoby, aby się zgodziły na kandydowanie do rady. Obrazowo odkrywają ten model działania członkowie rad: mnie proboszcz poprosit (...) żeby się zgodzić o startowanie na tej liście wyborczej (K-57:19); u nas proboszcz chodzit dlugo po wiosce i szukat kandydatów (K-58:30) lub proboszcz powiedzial, daj się wybrać, bo jak nie, to ja sam cię mianuje (Sz-01:23:03).

Członkowie rad są świadomi potrzeby odnawiania składu rady, co wyrażają przykładowo w taki sposób: swoją osobę stawiam na końcu, a staram się włączyć te, które sa możliwe do pozyskania (W-02:40:50). Dostrzegają kluczową rolę właściwego doboru składu rady, ponieważ dostrzegają, że niektórzy zapisza się, a potem ich nie ma (W-02:42:02) oraz jak proboszcz po latach zapoznat się ze swoja parafia, niech wybierze tych, którzy coś soba reprezentuja (W-02:42:53).

Średnia wielkość parafialnej rady duszpasterskiej w Polsce w 2012 r. wynosiła 14,5 osób. W Polsce dominują rady, które liczą 13 osób. Istnieje silna zależność 
pomiędzy wielkością rady a wielkością parafii: w większych parafiach rady zazwyczaj są liczniejsze.

\section{Motywacja uczestniczenia w parafialnej radzie duszpasterskiej}

Z przeprowadzonych badań wynika, że członkowie parafialnych rad duszpasterskich kierują się wewnętrzną (duchową) oraz religijną motywacją. Wskazują na to takie przykładowe wypowiedzi: Mam trochę obowiazków, prowadze firmę, ale jestem $z$ kolei szczęśliwa, bo więcej jestem $w$ kościele, więcej myśle o tym, a wcześniej to było różnie (...) cieszę się, że jestem bliżej Boga i mogę być pomocna tym ludziom (W-02:52:19); Naszym celem jest osobista świętość (W-25:00); Czuję, że jestem bliżej Pana Boga (Sz-01:28:20), czy też: Jesteśmy bliżej tego [Kościoła] (K-01:06:38).

Bardziej szczegółowo wśród motywów uczestniczenia w radzie można wyróżnić poczucie religijnej misji (apostolstwa). Osoby, które radę parafialną traktują jako przestrzeń realizacji takiego posłannictwa, mówią o niej w ten sposób: Jest to powołanie do bycia aktywnym członkiem Kościoła (W-22:56); Za najważniejsze uważam to, że moge stworzyć jakieś dobro, które się potem rozprzestrzenia wśród ludzi i powiedzmy aktywizuje społeczeństwo, tę parafię (K-01:07:20); Jesteśmy przedtużeniem rąk księdza (W-03:03:53). Członkowie rad wskazują również na rolę świadectwa: To nasze świadectwo, nasza postawa świadczy o życiu parafii (W-21:00); W radzie sq osoby, które sq realizacja Kościoła, którzy sq świadectwem prawdziwej wiary (W-19:34).

Ponadto w wypowiedziach członków rad pojawia się wyjaśnianie uczestnictwa $\mathrm{w}$ radzie poprzez poczucie obowiązku oraz gotowość do pomocy przede wszystkim proboszczowi, jak i całej parafii: Jest taka dobra zasada, że księdzu proboszczowi sie nie odmawia. Jak ksiadz proboszcz prosi o pomoc, to tej pomocy trzeba mu udzielić (W-20:20); Poczułem się odpowiedzialny za parafię (...) za środowisko, za parafię, zależy mi na tym (K-57:22), czy też Nie można inaczej (W-24:35); Jestem $w$ radzie, żeby pomóc innym, pomóc parafii (W-02:57:10), a także: W radzie jestem dlatego, że lubię pomagać ludziom, a przede wszystkim swojemu księdzu proboszczowi (W-02:58:52). Jestem po to, żeby pomagać (W-03:05:10).

Ponadto członkowie rad wskazują na satysfakcję, która jest motorem ich działania $\mathrm{w}$ strukturach parafialnych. Tak jedna $\mathrm{z}$ osób z parafialnej rady duszpasterskiej w południowej Polsce: Myślę, że to jest głównie satysfakcja, że człowiek coś zrobit (...) to jest budujace (K-01:01:01) lub ktoś inny: Ale jest tez ogromna satysfakcja, że jestem w tej radzie, że mogę pomóc, sprzedać ta wiedze swoja, moge kimś pokierować, czy ktoś pokieruje mna, tylko się z tego cieszyć, taka jest praw$d a$, coś możemy pożytecznego dla tych drugich ludzi zrobić $i$ dla siebie tak samo (K-01:04:04). 
Osoby zaangażowane w rady wskazują również na poczucie wspólnoty, które motywuje ich działania. W tym sensie wskazują najczęściej na radę jako okazję do poznawania ludzi oraz nawiązywania z nimi relacji, jak np. To nasza parafia, nasz kościót (W-20:39), czy też Nie wyobrażam sobie parafii, gdzie nikogo nie znam (W-22:05); [Ludzie] przestali być dla mnie anonimowi (W-25:40).

Nie oznacza to, że członkowie rad nie dostrzegają trudu związanego z własną pracą na rzecz parafii. Często wskazują na brak czasu: jest to poświęcenie $i$ to olbrzymie poświęcenie czasu, który ja jako ojciec czworga dzieci powinienem poświęcić dzieciom (K-01:05:55). Jednak mimo to, że jest to bardzo duże obciażenie (K-01:08:35), a nawet też jakiś ciężar, krzyż (Sz-01:42:05) członkostwo $\mathrm{w}$ radzie nie jest powodem do narzekania.

\section{Sposób prowadzenia prac parafialnej rady duszpasterskiej}

Zebranie rady zwoływane jest najczęściej z ambony w czasie nabożeństw. Zdarza się również, że proboszcz informuje poszczególnych członków indywidualnie. Na funkcjonowanie rad duszpasterskich w parafiach wyraźnie oddziałują zarządzenia diecezjalne dotyczące rad. Ich członkowie mają świadomość, że „ksiadz proboszcz z jakiegoś wzorca korzystal” (Sz-29:40) w kreowaniu rady. „Byty sygnaty $z$ diecezji (...) że należy tworzyć duszpasterskie ra$d y$ ".(W2:01:51:29). Z drugiej strony członkowie rad często nie znają statutów, w oparciu o które funkcjonują ich gremia. Na taki stan rzeczy wskazuje przykładowa wypowiedź jednego z członków: „pierwszy raz styszę, żeby rada miała być oparta o statut" (K-15:00). Zebrania odbywają się najczęściej w sposób formalny, często zakończone są głosowaniem, spisaniem protokołu oraz podpisami na liście obecności, tak jak to opisuje jeden z radnych: „Za każdym razem jest podpisywana lista obecności" (K-25:52). W małych parafiach proboszczowie również często spotykają się z członkami rady indywidualnie, a nawet radni spotykają się ze sobą: „ponieważ parafia jest mata, niektóre sprawy dyskutujemy niezależnie od spotkań rady, doraźnie się spotykając" (K-34:06). Z badań wynika ponadto, że w radach funkcjonujących od dłuższego czasu wymiana członków następuje rzadko. Większość parafialnych rad duszpasterskich (40\%) spotyka się raz na kwartał, około 30\% rzadziej niż raz na kwartał, a około $20 \%$ częściej, tak jak to przedstawia poniższa tabela.

Tab. 4. Częstotliwość spotkań parafialnych rad duszpasterskich

\begin{tabular}{|l|c|}
\hline \multicolumn{1}{|c|}{ Częstotliwość spotkań } & W procentach \\
\hline Ogółem & 100,0 \\
\hline raz w tygodniu & 0,2 \\
\hline dwa razy w miesiącu & 0,9 \\
\hline
\end{tabular}




\begin{tabular}{|l|c|}
\hline raz w miesiącu & 10,9 \\
\hline raz na kwartał & 40,0 \\
\hline dwa razy w roku & 14,1 \\
\hline raz w roku & 1,9 \\
\hline kilka razy w roku & 5,9 \\
\hline trzy razy w roku & 8,8 \\
\hline okazjonalnie & 0,6 \\
\hline jeżeli jest taka potrzeba & 5,3 \\
\hline raz na dwa miesiące & 9,2 \\
\hline brak danych & 2,1 \\
\hline
\end{tabular}

Źródło: ISKK

Ambona służy również do informowania wiernych o wynikach prac rady duszpasterskiej. Radni uważają, że informacje z prac rady docieraja do ludzi (W-02:24:05) oraz że proboszcz przekazuje informacje na bieżaco (K-29:58). $\mathrm{W}$ tym celu nierzadko wykorzystywana jest również strona internetowa, gazetka parafialna czy gablota ogłoszeniowa.

Członkowie rad są świadomi wrażliwości przekazywanych informacji na temat posiedzeń rady. W ten sposób opisują ten problem: Nadmiar informacji mógtby doprowadzić do pewnego załamania, jesteśmy tego świadomi $i$ dlatego ograniczamy przeptyw informacji (W-02:18:48) oraz Myśmy mieli rozmowe z księdzem proboszczem, które informacje z zakresu finansów można upubliczniać, a które nie (W-02:29:56). Ponadto radni dostrzegają, że ponieważ rada duszpasterska jest ciałem doradczym proboszcza, więc nie wiem, czy ma być informacja, $\dot{z}$ e to rada parafialna [coś konkretnego ustaliła], bo mamy wspierać proboszcza. On jest odpowiedzialny za parafie $i$ wykazywanie się działalnościa rady parafialnej jest niepotrzebne. Albo się angażujemy wszyscy a niektórzy maja głos doradczy, bo sa do tej rady powolani, albo uznajmy, że jest jakaś dwuwtadza, z których jedna musi się wspierać, że to rada parafialna. Może się pochwalić, że dobrze wspótpracuje, ale nie sadze, żeby to byto konieczne (W-02:27:55). Z tego wynika praktyk utajniania obrad rady. W jednej z parafii zostata podjęta decyzja, że wszystkie dyskusje sa do wewnętrznego użytku rady, a decyzje podjęte sq jawne (K-39:38). Często obrady rady sq ściśle tajne, nie może być [wskazywania, że] pan powiedzial"' (K-36:50).

$\mathrm{W}$ radach funkcjonujących według modelu reprezentacyjnego informacja z obrad rady trafia bezpośrednio do poszczególnych wspólnot parafialnych i dalej poprzez członków wspólnot rozchodzi się po parafii. Wyraża to następujące stwierdzenie: $U$ nas $w$ radzie sa prezesi wszystkich stowarzyszeń $i$ kót (...) więc pewne sprawy sa potem przekazywane czlonkom (...) bardzo duża grupa parafian dowiaduje się (W-04:32:03). 


\section{Tworzenie więzi w obrębie rady}

W większości rad duszpasterskich nie jest praktykowana stała formacja jej członków. Najczęściej formowanie radnych odbywa się przy okazji uroczystości takich jak Boże Narodzenie poprzez konferencję czy przemówienie proboszcza. Jedynie w niektórych parafiach z okazji Roku Wiary, przed spotkaniem rady proboszcz wygłaszał konferencję katechizmową. Dostrzega się również swoiste konkurowanie pomiędzy praktykowaniem w radzie formacji członków, a jej zaangażowaniem administracyjnym i działaniowym w parafii. Oznacza to, że to właśnie w parafialnych radach duszpasterskich, które podejmują się konkretnych działań w parafii, formacja członków jest częściej pomijana. Rzadko rady organizują wspólne wyjazdy pielgrzymkowe lub rekolekcje. W radach działających według modelu reprezentacyjnego formacja przerzucana jest na wspólnoty parafialne, z których pochodzą członkowie rady. Z drugiej jednak strony wywiady z członkami rad wskazują, że osoby te dostrzegają rolę formacji i oczekują jej od swych duszpasterzy.

Sporadycznie w radach organizowane są nieformalne spotkania, takie jak wspólne grillowanie czy świętowanie imienin lub jubileuszu proboszcza. Świeccy bardzo pozytywnie oceniają tego typu inicjatywy, o czym świadczą przykładowe wypowiedzi członków rad: Mieliśmy grilla z księdzem proboszczem w podziękowaniu za prace na rzecz Kościoła (Sz-01:04:25). Takim nieformalnym spotkaniem rady parafialnej sa imieniny proboszcza, gdy po prostu wszyscy się zwalamy hurtem $i$ proboszcz jest $w$ ten czas biedny, jak to wszystkich pomieścić przy stole (Sz-01:05:25).

W większości rad więzi pomiędzy członkami są raczej formalne, na co wskazują przykładowe wypowiedzi: Nic nas nie łaczy, ale też nic nas nie dzieli (W-10:56); Spotykamy się głównie w kościele, ale sa jakieś więzi na bazie kościota. Kościót nas jakość jednoczy. Poznajemy się najpierw na mszy, potem bo jest okazji do zrobienia czegoś wspólnie (W-12:29); Ci czterej czlonkowie rady, nie mam z nimi jakiegoś bliższego kontaktu poza spotkaniami (...) ale marzyłoby mi się, żeby w radzie byli tacy ludzie, z którymi chciatbym się spotkać na Eucharystii (W-02:45:50); Oprócz spotkań do rozwiazywania doraźnych problemów, spotkań ze tak powiem towarzyskich nie praktykuje się poza takimi jak jajko czy opłatek (02:49:30); Znamy się, szanujemy, orientujemy się, co kto daje i może dać (W:02:53:25).

\section{Rola proboszcza w parafialnej radzie duszpasterskiej}

Z badań wynika, że członkowie rad na ogół pozytywnie oceniają swojego proboszcza. Najczęściej taka ocena opiera się na jego pracy organizacyjnej. Niejednokrotnie w wypowiedziach członków rad pojawiała się ocena, że nasz proboszcz jest zreszta świetnym gospodarzem (W-04:02:56). Ponadto świeccy widzą 
wpływ charakteru proboszcza na sposób jego działalności w radzie, o czym świadczy przykładowa wypowiedź: jeśli by przyszedt taki energiczny i taki naprawde peten zapatu jak ten, którego mamy [proboszcz] to normalnie wszystko działa, ale gdyby taki byt trochę wolniejszego charakteru i temperamentu, to jakoś też trzeba umieć wspótpracować i robić coś (W-04:21:40).

W parafiach, gdzie sprawnie funkcjonują rady, członkowie nie skarżą się na despotyczność proboszcza. W trakcie badań nie pojawiły się ani razu jakiekolwiek zarzuty pod adresem proboszcza lub innych księży w parafii. Natomiast pojawiały się wypowiedzi wskazujące, że proboszczowie potrafią słuchać świeckich oraz z nimi współpracować. Tak na przykład członkowie rady z diecezji w północno-zachodniej Polsce wyrażali się o swoim proboszczu: ksiądz proboszcz chętnie realizuje pomysty, które mu podsuwamy (...) nigdy nie ma między nami konfliktu, czy żebyśmy się nie zgadzali (Sz-25:30) lub z centralnej Polski: Nasz proboszcz jest człowiekiem, którego można przekonać. Stucha argumentów i po wystuchaniu argumentów potrafi zmienić zdanie (W2-02:10:40) oraz z południowej części kraju: proboszcz chętnie stucha, choć czasem zrobi po swojemu (K-15:30) i proboszcz liczy się z tym, co powiemy (K-54:47).

Badania wykazały, że proboszcz realnie zajmuje centralne miejsce w parafialnej radzie duszpasterskiej. Członkowie wyraźnie wskazują, że sposób funkcjonowania rady niemal w całości zależy od proboszcza, co odzwierciedla następująca wypowiedź: Mi się nasuwa taki wniosek (...) że wszystko, cała ta działalność rady parafialnej $i$ prowadzenie $i$ wszystkie te akcje to zależy od proboszcza (...) bo jaki jest proboszcz, tak będzie działała rada (K-30:21) lub też Rada bez proboszcza nie zrobi nic (K-20:54) oraz wszystko zaczyna sie od proboszcza (K-48:29).

Proboszcz jest przewodniczącym rady, zwołuje zebrania rady oraz nimi kieruje, o czym w ten sposób wyrażają się członkowie rady: Choćby rada dobijata się drzwiami i oknami, to on powie nie i koniec. [Proboszcz] podejmuje decyzje ostateczna, rada jest tylko ciałem doradczym (W-02:28:56). Nie przeszkadza to temu, aby w trakcie spotkań rady dochodziło do dyskusji i wymiany poglądów. Członkowie rad opisują to w ten sposób: Proboszcz prowadzi [spotkanie] Nie zawsze członkowie rady zgadzaja się z opinia albo koncepcją księdza proboszcza, ale wspólnie wypracowujemy jakoś konsensus $i$ że tak powiem posuwamy sprawe do przodu (W-04:15:43); my dyskutujemy, każdy ma prawo wypowiedzieć swoje zdanie, a potem wszystko jest podsumowywane przez proboszcza. Proboszcz mówi to można, tego nie można, to jest zgodne lub niezgodne (...) żeby nie byto jakichś tam nauczań niezgodnych z litera prawa czy Pismem św. (W-04:10:20). $\mathrm{W}$ trakcie spotkania rady proboszczowie zazwyczaj prezentują tematy związane z parafią i pytają o zdanie członków, dają również czas na przedstawienie wolnych wniosków. 
Zdarza się, że formalnie w niektórych radach duszpasterskich świeccy pełnią rolę przewodniczących. Nie zmienia to jednak nadrzędnej roli proboszcza w radzie, jak opisuje to jeden z członków: ja jestem tym przewodniczacym, ale proboszcz jest naczelnym (W-04:08:34). Ponadto 92\% proboszczów pozytywnie ocenia działanie rady duszpasterskiej w swojej parafii.

\section{Skuteczność działań parafialnej rady duszpasterskiej}

Członkowie rad potrafią wskazywać konkretne inicjatywy duszpasterskie, które zostały podjęte przez radę (np. katechezy, zaproszenia na rekolekcje), ale nie oceniają skuteczności rady tylko przez pryzmat konkretnych inicjatyw, ponieważ proboszcz potrzebuje tez wsparcia (W-03:16:25), a rada jest po to, żeby podyskutować nad tymi sprawami, które już się dzieja (W-01:52:23).

Oddziaływanie parafialnej rady duszpasterskiej funkcjonującej według modelu eksperckiego dokonuje się poprzez poszczególnych członków rady indywidualnie. Natomiast rada według modelu reprezentacyjnego oddziałuje poprzez wspólnoty parafialne, z których reprezentanci wchodzą w skład rady. Prezentuje to poniższa rycina.

DORADZANIE

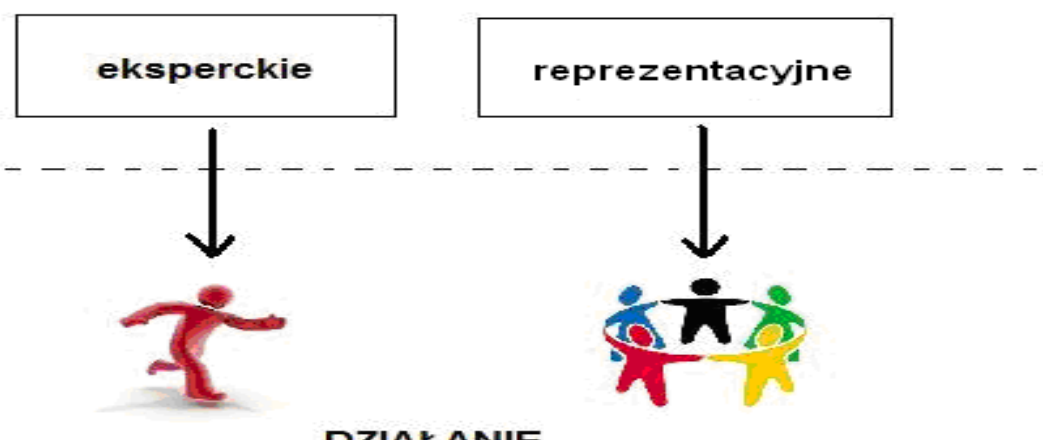

DZIAKANIE

Z danych uzyskanych ze wszystkich parafii w Polsce wynika, że wśród spraw, w których doradzają rady duszpasterskie, dominują inicjatywy charytatywne $(27 \%)$ oraz życia liturgicznego i sakramentalnego (25\%). 16\% parafialnych rad duszpasterskich doradza w zakresie inicjatyw apostolskich, $12 \% \mathrm{w}$ zakresie inicjatyw katechetycznych oraz $8 \%$ misyjnych. Jednocześnie co trzecia parafialna rada duszpasterska doradza w sprawach ekonomicznych. 


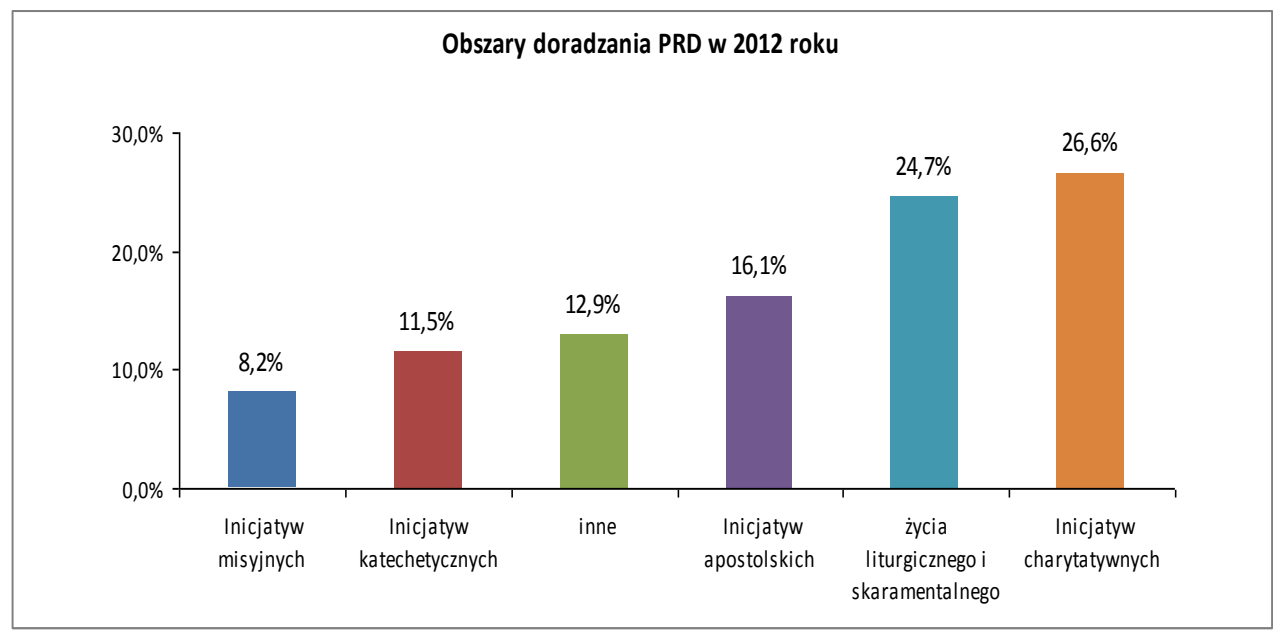

Ponadto niemal połowa parafialnych rad duszpasterskich podejmuje konkretne działania w parafii. Najczęstszym polem działalności parafialnych rad duszpasterskich są inwestycje (26\%), sprawy duszpastersko-apostolskie (22\%), charytatywne (13\%), administracyjne (12\%), następnie liturgiczne (12\%), gospodarcze $(11 \%)$ oraz społeczno-kulturalne $(2 \%)$.

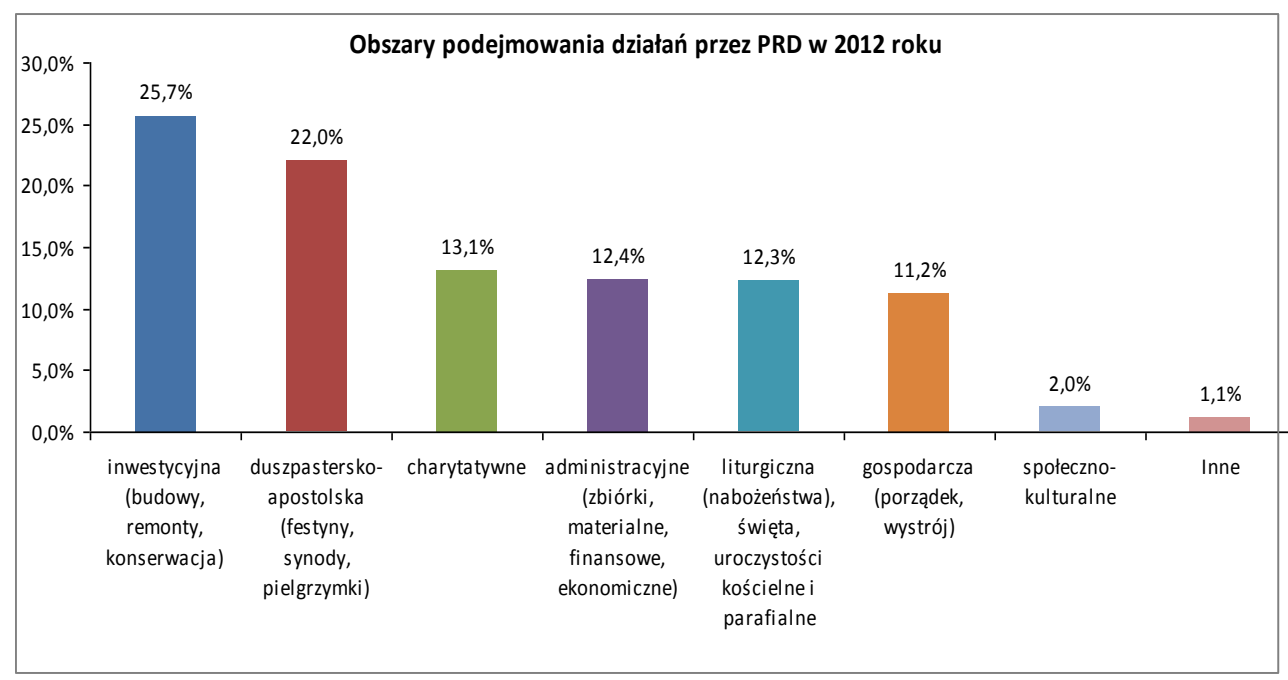

Wynika $\mathrm{z}$ tego, że parafialne rady duszpasterskie dużej mierze podejmują konkretne działania oraz, że zarówno w zakresie doradzania jak i działania wchodzą one w kompetencje parafialnych rad ekonomicznych. Połowa zbadanych 7.117 parafialnych rad duszpasterskich nie przygotowuje programu duszpasterskiego dla swojej parafii $(49,5 \%)$; niemal tyle samo taki program tworzy $(45,4 \%)$. 


\section{Wnioski}

Przeprowadzone przez Instytut Statystyki Kościoła Katolickiego badania ukazały intensywny proces rozwoju parafialnych rad duszpasterskich w Polsce w ostatnich latach. Istnieją podstawy, aby w rozwoju rad dostrzegać dalszy etap rozwoju struktury parafialnej w Polsce. Po okresie intensywnego tworzenia nowych parafii obserwuje się proces budowania struktur wewnątrz-parafialnych. $\mathrm{W}$ niektórych diecezjach etap ten został rozpoczęty już kilka lat temu. Jednakże często parafialne rady duszpasterskie $w$ tych diecezjach nie funkcjonują w sposób sprawny oraz działają niezgodnie $\mathrm{z}$ normami prawnymi. W wielu innych diecezjach wciąż trwa etap tworzenia rad.

$\mathrm{Z}$ drugiej jednak strony, przykłady aktywnie funkcjonujących parafialnych rad duszpasterskich w Polsce wskazują na twórcze i pozytywne oddziaływanie tych struktur na przekształcanie parafii we wspólnotę (community organizing). Tam, gdzie rady realnie działają, integrują parafię, włączają i aktywizują mieszkańców we wspólnotę parafialną, budują więź pomiędzy świeckimi a duszpasterzami oraz animują działalność duszpasterską z zachowaniem centralnej roli proboszcza w parafii. 